\title{
Piększydta propagowane w polskich herbarzach wydanych w XVI wieku
}

\section{Beauty products propagated in Polish herbaria published in the sixteenth century}

\author{
Lilianna Wdowiak ${ }^{\bowtie}$ \\ ${ }^{1}$ Pomorski Uniwersytet Medyczny w Szczecinie, Samodzielna Pracownia Edukacji Medycznej, ul. gen. Dezyderego Chłapowskiego 11, 70-103 Szczecin \\ $\triangle$ lilianna.wdowiak@pum.edu.pl
}

\begin{abstract}
Introduction: Herbs have been used in medicines and cosmetics for centuries. Their ability to treat different skin diseases, and to adorn and improve the skin's appearance are well-known. Similarly, as in other European countries, in Poland it began in the sixteenth century, with the publication of so-called gardens of health (hortus sanitatus) or encyclopaedic herbaria, containing not only knowledge of plants and their use, but extended news from the world of animals and minerals.

The aim of the study was to determine when the use of cosmetics was mentioned for the first time, and what ways of body care were emphasized in the Renaissance herbaria. It was assumed that the needs of people in Poland at that time were not different from the expectations of other people in Europe.
\end{abstract}

Materials: We analyzed four herbaria which appeared in Poland in the sixteenth century. They were written by Stefan Falimirz, Hieronim Spiczyński, Marcin Siennik, and Marcin from Urzędów. The herbaria duplicated the knowledge learned from ancient authors, and only Marcin from Urzędów added personal observations in his work. The Polish translation of "Segreti del reverendo donno Alessio Piemontese", very popular in Europe as a guide to cosmetics, was published by Marcin Siennik.

Conclusions: Herbaria contain plenty of information about the care of skin, hair, nails and teeth, as well as perfume. In sixteenth century Poland there was great public demand for this type of knowledge.

Keywords: history of cosmetics; herbaria; hortus sanitatis.

\begin{abstract}
ABSTRAKT
Wstęp: Zioła są stosowane w lekach i kosmetykach od wieków. Dobrze znane są możliwości leczenia różnych chorób skóry, jej ozdabiania i poprawiania wyglądu. Podobnie jak w innych krajach Europy, w Polsce zaczęto w XVI w. wydawać drukiem tzw. ogrody zdrowia (hortus sanitatus), czyli encyklopedyczne zielniki (herbarze) zawierające nie tylko ówczesną wiedzę o roślinach i ich wykorzystaniu, lecz także poszerzone o wiadomości ze świata zwierząt i minerałów.

Celem pracy było ustalenie, kiedy pojawiły się pierwsze wzmianki o stosowaniu kosmetyków oraz na jakie sposoby dbałości o ciało był kładziony nacisk w renesansowych herbarzach. Przyjęto założenie, że potrzeby ówczesnych Polaków nie różniły się od oczekiwań innych mieszkańców Europy.
\end{abstract}

Materiały: Analizie poddano 4 herbarze, które ukazały się w Polsce w XVI w. Napisali je: Stefan Falimirz, Hieronim Spiczyński, Marcin Siennik i Marcin z Urzędowa. W większości powielały one wiedzę zaczerpniętą od autorów starożytnych, jedynie Marcin z Urzędowa dodał do swojej pracy własne ustalenia. Polskie tłumaczenie „Segreti del reverendo donno Alessio Piemontese”, bardzo poczytnego w Europie poradnika dotyczącego głównie kosmetyków, zamieścił Marcin Siennik.

Wnioski: W herbarzach zawarto liczne informacje na temat pielęgnacji skóry, włosów, paznokci, zębów i pachnideł. W Polsce w XVI w. istniało na taką wiedzę duże zapotrzebowanie. Słowa kluczowe: historia kosmetyków; herbarze; ogrody zdrowia.
O odpowiedni wygląd osobisty, zarówno w europejskim kręgu kulturowym, jak i na innych kontynentach, troszczono się w każdej epoce, zwłaszcza w wyższych sferach społecznych. Wizytówkę świadczącą o zdrowiu stanowiła skóra. Szczególną uwagę zwracano zwłaszcza na twarz, gładkość cery, brak przebarwień, brodawek, ropnych wykwitów skórnych, „dziobów" po ospie, blizny, zmarszczki, jasną karnację ozdobioną rumieńcem, wygląd oczu i brwi, jędrność ust. Do połowy XVI w. przetrwała jeszcze średniowieczna moda na wysokie czoła u kobiet, wyrywanie brwi i rzęs, która pojawiła się we Włoszech w XIV w. [1]. Dbałością otaczano włosy. Rzadkie sploty u pań i połyskujące łysiny u panów nie były mile widziane, a i siwizna dodawała lat. Od czasów starożytności włosy farbowano, mniej lub bardziej otwarcie, nawet w średniowieczu, więc w czasach Odrodzenia również tak czyniono. Po farby sięgały nie tylko kobiety, ale i mężczyźni. Pomijając kwestię zmieniającej się mody na noszenie bród i wąsów przez mężczyzn, starano się zlikwidować zbędne owłosienie. Zwykle eleganckie kobiety usuwały włosy wyrastające nad górną wargą czy na brodzie, ale depilację przeprowadzano również w innych miejscach ciała, w zależności od panującej mody (ryc. 1).

Istotną sprawę stanowił nieświeży oddech z ust, efekt zniszczonych przez próchnicę zębów, bądź stany zapalne dziąseł zaatakowanych szkorbutem. Wybielanie i czyszczenie zębów stawało się kolejnym wyzwaniem. Usiłowano zadbać o ręce i paznokcie. Ważną rolę odgrywał zapach całego ciała. Wobec 


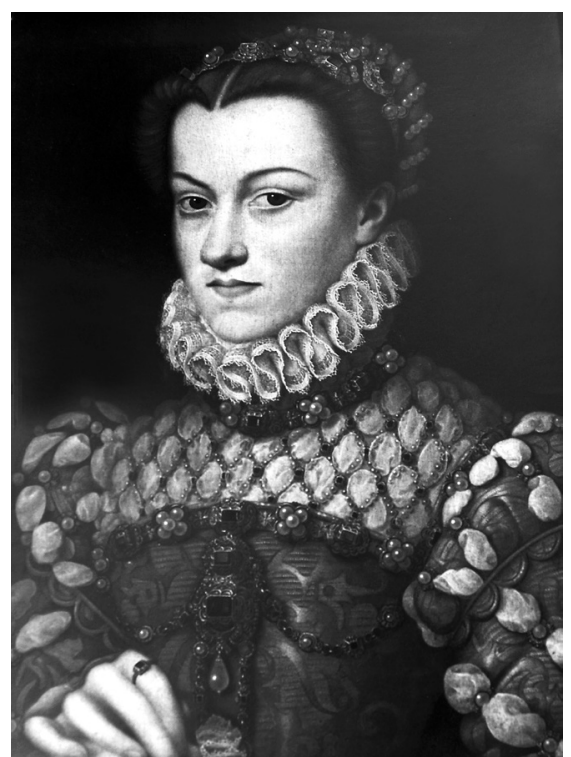

RYCINA 1. Kobieta w stroju renesansowym. Portret nieznanego artysty

rozpowszechniania się syfilisu starano się ukryć pod ubiorem lub zatuszować kosmetykami kiłowe wykwity. W renesansowych Włoszech, a później w całej Europie, popularność zyskały nie tylko herbarze (encyklopedyczne zielniki), ale i libri de segreti - poradniki zawierające m.in. receptury kosmetyczne oraz podające skład leków potrzebnych do użytku domowego czy środków czyszczących.

W literaturze polskiej termin kosmetyk pojawił się dopiero w drugiej połowie XIX w., a wcześniej był zastępowany terminem pięknidło - pisała Jankowiak [2], jednakże Brückner podawał, że do XVIII w. funkcjonował termin piękrzydło, a od XVIII w. - piększydło [3]. Ponieważ piększydło dla współczesnych Polaków stanowi słowo bardziej zrozumiałe od piękrzydła, postanowiono się nim posłużyć w tytule, chociaż w polskich renesansowych zielnikach nie używano tego terminu.

Celem pracy stało się sprawdzenie, w których polskich renesansowych zielnikach pojawiły się pierwsze wzmianki o stosowaniu kosmetyków oraz na jakie sposoby dbałości o ciało był kładziony nacisk w herbarzach. Przyjęto założenie, że potrzeby ówczesnych Polaków nie różniły się od oczekiwań innych mieszkańców Europy.

„Współczesne zainteresowanie botaniką renesansu jest wielopoziomowe, wynikające z interdyscyplinarnych badań rozpoczętych na niektórych polach, ale pozostających wciąż jeszcze w stadium inicjalnym" - napisała w 1997 r. Zemanek [4]. Jak się wydaje, w przypadku piększydeł, pomimo upływu dwóch dekad, niezbyt wiele na tym polu zrobiono i problematyką kosmetyczną polskiego Odrodzenia nie zajmowano się zbyt często. Poruszał ją w swoich pracach głównie Bela $[5,6,7,8]$. Okazjonalnie opisując poszczególne herbarze czy inwentarze apteczne bądź pisząc prace poświęcone zupełnie innej tematyce, wspominano również o środkach służących upiększaniu oraz pielęgnacji ciała. Czynił tak na przykład Kuchowicz [9], ale podobnie postępowali również inni autorzy. Szostak w swoim dziele o farmakognozji i aptekarstwie napisał o przygotowywaniu różnego rodzaju wódek (rozumianych inaczej niż we współczesnym znaczeniu [5, 10]), mazideł lub maści aplikowanych w celu polepszenia kondycji skóry i likwidowania zmian [11], jednakże w swoich najważniejszych badaniach skupił się jedynie na 3 zielnikach: Falimirza, Spiczyńskiego i Siennika. Inną pozycją tegoż autora (gdzie pisał o renesansowej higienie) było omówienie „Lekarstw doświadczonych...” Marcina Siennika [12], kolejnego poradnika cieszącego się popularnością w XVI i XVII w. „Lekarstwa doświadczone...” w połowie były poświęcone poradom dla ludzi i zawierały informacje nie tylko o leczeniu, lecz i o pielęgnacji oraz o ozdabianiu ciała, natomiast druga ich część dotyczyła koni i opieki nad nimi [13].

Jak wspomniano wcześniej, pierwsze wzmianki o sposobach pielęgnowania ciała $\mathrm{w}$ Polsce $\mathrm{w}$ języku polskim pojawiły się dopiero w pracach wydawanych w XVI w. Na początku XVI w. zaczynają ukazywać się drukiem tzw. ogrody zdrowia - publikacje o charakterze encyklopedycznym zawierające informacje o wszechstronnym wykorzystywaniu roślin, zwierząt czy minerałów [14]. Prekursorem tego typu opracowań w Polsce był Jan Stanko (1430-1493), lekarz Kazimierza Jagiellończyka. Napisany przez niego ok. 1472 r. „Antibolomenon...” nie został jednak wydany drukiem. Pierwszym wydrukowanym herbarzem stało się dzieło Aemiliusa Macera (70-16 r. p.n.e.) pt. „De Herbarum virtutibus cum veris figuris herbarium..." [15], które opracował doktor medycyny Szymon z Łowicza (ok. 1512-1538?). Chociaż niewielka praca (ok. 200 nienumerowanych stron) została wydana w języku łacińskim, Szymon z Łowicza zamieścił w niej polskie nazwy roślin, a także listę schorzeń, które z łaciny przetłumaczył na język polski. Jak twierdził Ziembicki, pierwsza edycja miała miejsce w $1532 \mathrm{r}$. [16]. O kosmetykach Macer, a za nim Szymon z Łowicza, nie wspominali.

W 1534 r. Stefan Falimirz (Falimierz) wydał „0 ziołach i mocy ich” [17]. Dzieło 4-krotnie przekraczało objętość tekstu Szymona z Łowicza i zawierało, oprócz przepisów potrzebnych do sporządzania lekarstw, liczne wiadomości dotyczące środków kosmetycznych. We wstępie Falimirz zaznaczył, iż praca stanowiła jedynie tłumaczenie z autorów łacińskich. Przypuszczalnie oparł się na „Herbarzu” wydanym w Passawie w 1485 r. oraz „Ortus sanitatis”, który ukazał się w Moguncji w $1491 \mathrm{r}$. [18]. Brak ponumerowanych stron znacznie utrudniał wyszukiwanie materiałów, bowiem ówczesnym zwyczajem tekst został podzielony na rozdziały, a te na listy. Jeden list mógł istnieć na kilku stronach.

Falimirz podawał prawie 10 remediów na porost włosów, ich czernienie, natomiast niewiele z nich mówiło o tym, jak włosy rozjaśniać („iasne, czy żółte włosy czynić”). Zamieścił również receptę, jak pozbyć się łupieżu głowy. Najwięcej przepisów dotyczyło „spędzania krost”, czyli wysypek i owrzodzeń (spośród chorób skóry osobno wyróżniano wówczas parchy, świerzb, liszaje i „trądy”). Zapewne ówczesnym mieszkańcom Europy zależało na nieskazitelnym obliczu, gdyż Falimirz oprócz środków do likwidowania zaskórniaków podawał kilka sposobów pozbycia się „piegów z licza i inszych szkaradności”, m.in. napisał o zaletach babki (Plantago sp.): „Sok z tego ziela strochą octu, gdy pomażesz tym piegi zginą zlicza". Przekazywał również skład lekarstw „przeciw ogorzelinie”, czyli opaleniźnie, jak „licze czudne uczynić”, „płeć wygładzić”, 
„Siność pod oczyma spędzić”, „opuchliznę pod oczyma spędzić”, „starzenie się warg naprawić” czy sprawić „rumianość licza” i „na liczu barwę czudną czynić”. Liczne sposoby dotyczyły „oddalania smrodu z ust” lub „odejmowania smrodu z dziąseł”, jak i zamieszczony został przepis remedium na bielenie zębów. Umieszczenie recepty na „zatłumienie z siebie woni czosnkowej" może wskazywać na to, iż chyba dość dużo czosnku wówczas używano [17].

Falimirz osobną część pracy poświęcił paleniu wódek (ryc. 2). Już w opisie pierwszej wódki - ałunowej, oprócz zastosowania lekarskiego, podawał: „odejmuje smród, a zwłaszcza między szparami u nóg, albo za pazuchami, albo około łona”. Wódka anyżowa „rumienność lica czyni”, dziewannowa, z kwiecia "gdy nią lice umywa piękność i rumianością dawa, piegowate i żółte flaki i insze szkaradności ściera”, , ,lanczaną wódką umywać twarz, zmazy z niej ściera”, wódka „miętczana” (miętowa) „oddala cuchnienie z ust”, wódka z „matki bożej włosek (...) jest bardzo dobra tym ludziom, którym włosy z głowy padną"; wódka „rozmarinowa” również służyła temu celowi. Wódka różana „dziąsła potwierdza y wonią ustam daie przyjemną, gdy komu z ust cuchnie. (...) Gdy ktho sobie licze umywa różaną wodą, czyni płeć wdzięczną a lubieżną". Falimirz zamieścił również receptę na „wodkę bardzo dobrą wybielającą twarz omywaiąc przez dzień albo dwa”, która składała się z wódek pędzonych z kwiatów grzybienia, kwiatów benedyktowych, kwiatów bzu, fiołków białych, kwiecia tarnkowego. Ponieważ rośliny kwitły w różnych miesiącach, wódki należało sporządzać osobno, a potem je zmieszać i przepędzić przez alembik, a następnie przechowywać w przykrytej szklanicy. Inny przepis miał przywracać straconą urodę: „Wódka, która przywraca straconą krasę na obliczu. Naprzód weźmi Wódki

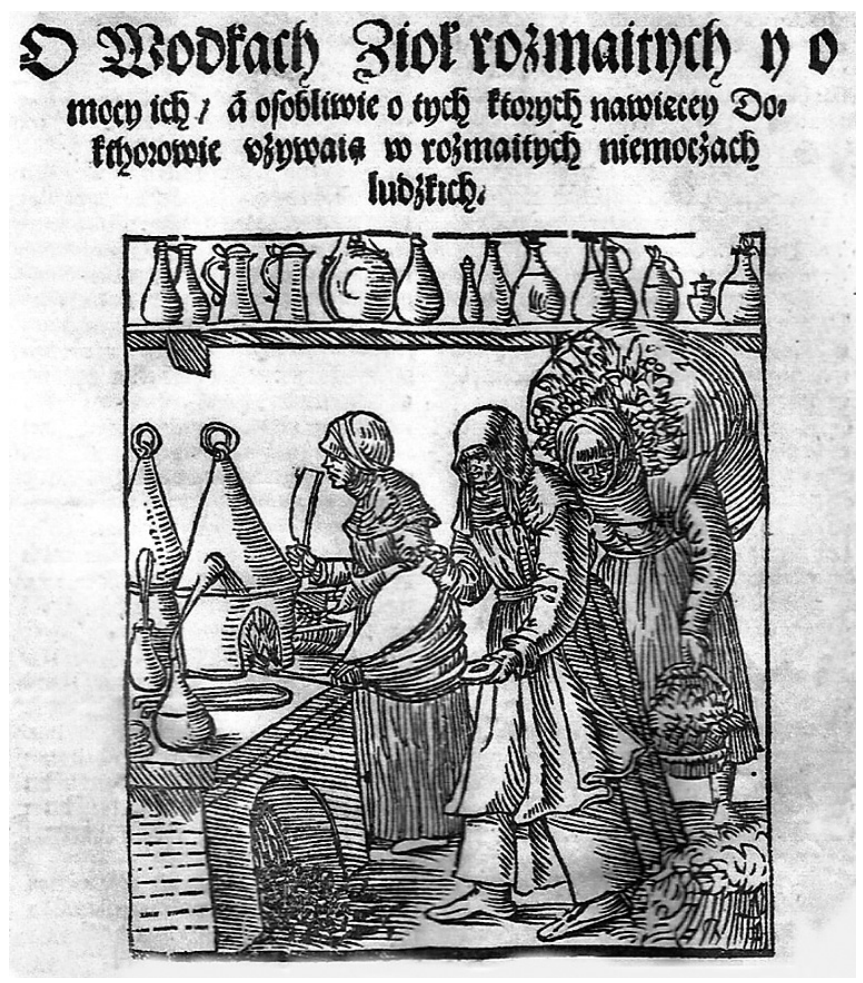

RYCINA 2. Palenie wódek - fragment karty z herbarza H. Spiczyńskiego
Bukwicowey, Rozmarynowey, Werbenowey, to iest Koszyszczkowey, Piołunowey, wszystkich równo zmieszay ie społem, a day stać na Słońcu przez ośm dni" [17].

Falimirz podawał również sposób przygotowania „wódki ku omywaniu brody po goleniu albo po łaźni”: „Weźmi podróżniku, a spal go na popiół, po tym z tego popiołu uczyń kałkus, czoby nie był barzo silny, potym tego kałkusu wezmi kwarte a włóż do niego trzy czwierci łotu Dragantu Camphori także wiele, a wlej społem do iakiey banie szklaney, albo czenowey flasze, zakryj dobre z wierzchu, a daj sthać aż to się tam rozpuści, potym to przecedź przez chustę, a wley zasie do banie. A tym sie umyway po łaźni" [17]. Gwoli wyjaśnienia słowem kałkus określano ług wapienny, a pod terminem dragant kryła się guma tragankowa z traganka gumodajnego (Astragalus gummifer - Fabaceae).

Wśród opisów wódek znalazły się także przepisy na wywabianie plam z jedwabiu i futer, a także środek mydłozastępczy, zatytułowany „Sprawa jedna ku umywaniu lica i rąk, która pachnie a czyni ciało białe jako mleko". Recepta przewidywała użycie dragantu, wódki różanej, jajka świeżego, którego białko należało ubić, krochmalu oraz mąki jęczmiennej. Inna wódka, sporządzona z mieszaniny licznych wódek, miała spędzać piegi. Kolejna wódka została określona jako „Woda sprawiona a barzo szlachetna woniaiąca", a w jej skład wchodziły m.in. wódka różana i piżmo.

Pośród wódek autor umieścił również środek do usuwania owłosienia złożony z aurypigmentu (ryc. 3), wapna, korzenia fiołkowego (kłącza kosaćca Iris sp.), które należało zmieszać z wodą, by nabrało konsystencji ciasta, nałożyć na ciało, poczekać aż zaschnie i zeskrobać drewienkiem, a potem ciało zmyć wódką różaną lub z jej braku - czystą wodą. W rozdziale

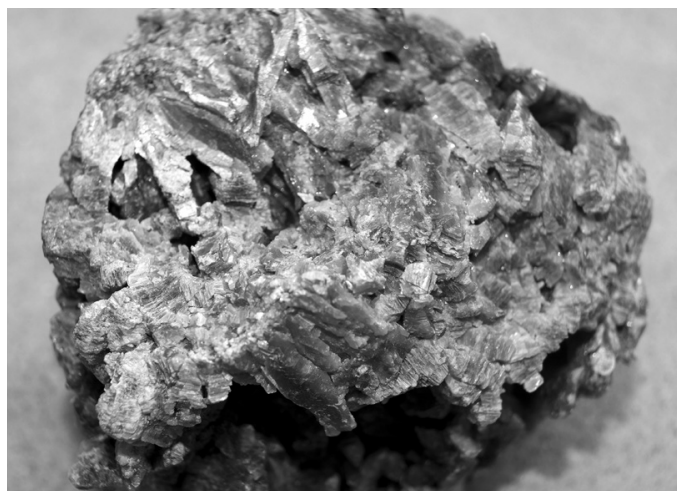

RYCINA 3. Aurypigment

poświęconym olejkom Falimirz podawał, jak sporządzić silnie pachnące remedium z goździków i małmazji. „Olejek rozkoszny a bardzo woniajączy” należało wlewać do wody do mycia [17].

Dziesięć lat później po dziele Falimirza ukazała się praca „O ziołach tutecznych i zamorskich...” napisana przez Hieronima Spiczyńskiego (?-1550) [19]. Autor głównie czerpał wiedzę z pracy Falimirza, o czym świadczy dosłowne przytaczanie określonych fragmentów prac, np. opisów zastosowania obrazków, rośliny wówczas polecanej „na czudność lica”, lilii złotogłów, przystępu albo konopi. Spiczyński w „Regestrze 
niemocy” wymieniał 15 środków „zganiających piegi i inne szkaradności”, a „czudność lica i płci” czyniło 16 preparatów. Na porost włosów na głowie i brodzie wyszczególnił także 16 remediów. „Smród z ust” oddalać miało 12 lekarstw, a 2 recepty dotyczyły bielenia zębów.

W rzeczywistości środków tych było więcej niż podawał w „Regestrze niemocy”, gdyż w końcowej części pracy, w rozdziale pt. „Lekarstwa doświadczone” przytaczał kolejne środki. Na piegi: „Bób naczczo zeżwawszy pomazać. Albo mąką pszeniczną z miodem pomazać toż czyni. Rzodkiew stłuczona z miodem takież. Łupiny z nóg kurzych na ogniu rozparzone, pomagaią, gdy tak ciepłemi lice pocierają. Sadło kacze i takoż łabęcie. Cynamon zeżwawszy pomazować lice. Kto pije serwatkę, giną mu piegi. Żółtek iaia upieczonego ciepłego przykładać, czarność odeimuje która iest pod skórą. Biała lebiodka warzona w winie czarną skórę na licu bieli umywaiąc. Thoż czyni piwonija. Bobek tarty z gęsim sadłem, gorczyca tarta z miodem, a z sadłem kokoszem. Korzeniem przestępowym rozmacziąc w occzie albo w zimnej wodzie lice pocierać, wszy tki zmazy odeymiesz. Krew czarnej kokoszy twarz czyści pomazuiąc. Toż czyni krew zaięcza”. W dalszej części tekstu poświęconemu piegom, Spiczyński wymieniał „zmazy”, dzieląc je na poszczególne kolory [19].

Spiczyński zamieszczał przepis: „Aby włosy na brwiach nie rosły: Pomazuj ów krwią żabek zielonych brwi, takież krew wężowa na brwi pomazana, niedopuszcza wyrastać włosom. Też rdza z żelaza z sinami [prawdopodobnie chodziło o mocz przypis autorki] rozpuszczona, a thym brwi maży, nie urosną włosy na nich. Takież krew nietoperzowa, nie dopuszcza włosom wyrastać na takim mieistczu ktore będzie pomazano" [19].

W latach 1543-1553 powstało dzieło Marcina z Urzędowa (1500? -1573) - „Herbarz Polski...” [20], które nie stanowiło tylko kompilacji tekstów łacińskich, lecz zawierało również wiele własnych spostrzeżeń Marcina z Urzędowa. „Herbarz...” został wydany po raz pierwszy 22 lata po śmierci autora, a 42 lata po jego napisaniu. Właściwie „Herbarz Polski...” był ostatnim wydanym w XVI w. zielnikiem, lecz skoro powstawał tuż po wydaniu pracy przez Spiczyńskiego, wydaje się uzasadnionym napisać o nim w tym miejscu.

Marcin z Urzędowa zawarł w nim ponad 600 opisów roślin [21], a ponadto relacje o zwierzętach i lekach z nich pozyskiwanych, jak również minerałach czy substancji w rodzaju np. octu, wina, olejków czy kamienia winnego. W przeciwieństwie do swoich poprzedników Marcin z Urzędowa w swoim dziele zamieścił bibliografię, a w tekście powoływał się na autorów przytaczanych informacji. Nie korzystał z tekstów polskich. Pośród środków kosmetycznych zwraca uwagę duża liczba remediów (15) polecanych na usuwanie blizn. Pośród roślin i tłuszczów odzwierzęcych „gubiących blizny” znalazły się m.in. takie środki, jak: grynszpan, miedź palona, ołów wypłukany, wapno czy kamień winny zwany wówczas „wainsteinem” czy „lagrem winnym”. Tego ostatniego związku uży wano także do barwienia włosów na rudo. Wśród 10 specyfików służącym farbowaniu włosów znajdowały się m.in.: kozieradka, bluszcz, bób, cyprys, len, mirt czy szałwia, a także zamorski lotos. Aż 18 środków było na „głowę oparszywiałą albo łysą”, 7 remediów posłużyć miało włosom „padającym” czyli osłabionym [20].
Marcin z Urzędowa również zajął się problemem usuwania niepożądanych włosów. Opisując aurypigment, który nazywał „arseniconem”, podkreślał jego „moc ogryzaiącą”. „Wygryza też tak mocno, że żelazo przeiada, dlatego gdzie chcą włosy, albo paznokcie, albo insze grubości spędzić, przykładaią". Twierdził, że mieszano aurypigment z żywicą sosnową lub sadłem i dopiero wówczas aplikowano go na skórę [20].

Jako pierwszy z polskich autorów podawał kosmetyki pomocne do pielęgnacji brwi, a nie do ich usuwania. Pośród nich wymieniał: rzodkiew, spicanardi (nard), żywicę sosnową oraz sadzę. „Sadze, zwłaszcza kadzidłowe, mirrowe, z terpentyny, z tyraku, z smoły są suchego przyrodzenia, zimnego a subtelnego: badzo potrzebne w lekarstwa ku oczom, y chędożeniu brwi: sadza z kadzidła nad wszystki insze przewissza..." - napisał [20].

Marcin z Urzędowa, pośród 13 środków pomocnych w likwidowaniu piegów, przytoczył za Dioskuridesem korzyści płynące z używania krwi zająca: „Zajęcza krew osobliwie wyczyścia piegi, i także grubość i zmarszczki na licu mażąc z nią; także ogorzenie na słońcu". Ogorzała, pełna innych niedoskonałości cera stanowiła ważki problem w czasach renesansu, bowiem Marcin z Urzędowa pisał o niej i w innych miejscach, np. omawiając „leliowy złotogłów”, jak zwano wówczas narcyz. Używano cebul rośliny: „Krosty parchowate albo trędowate na licu, takoż płeć na licu opaloną od słońca, z pokrzywnym nasieniem a z octem to korzenie stłukłszy, lice ponakładając, spędza”. Cerę i wargi radził pielęgnować za pomocą tłuszczu ptaków: „Sadło kokosze, gęsie barzo pomocne przeciw rozpadlinom na wargach pomazując, jasne lice czyni...” [20].

W „Herbarzu...” bardzo dużo receptur (aż 12) dotyczyło pielęgnacji paznokci. Autor doradzał aplikować na nie hałun (ałun), siarkę, a spośród roślin m.in. - batrachion, czyli jaskier, którego wymienił cztery rodzaje. „Przeto na chropawe paznokcie przykładając je, wygryzają y nowe narastają" - napisał o jaskrach. Dzisiaj do rodziny jaskrowatych (Ranunculaceae) zalicza się 75 gatunków rosnących w Polsce (ryc. 4) [20].

Do likwidowania „cuchnienia z ust” Marcin z Urzędowa polecał spośród polskich remediów owies i piołun, z egzotycznych: aloes, mirrę, „mastyx”, „hanyż”, „citrowe jabłko”. Pod tą ostatnią nazwą, sądząc z opisu, przypuszczalnie kryła się cytryna [20].

W 1568 r. Marcin Siennik wydał „Herbarz to jest ziół tutecznych, postronnych i zamorskich opisanie..." [22]. Podobnie jak poprzednicy zamieszczając informacje o poszczególnych roślinach, odnosił się również do ich właściwości kosmetycznych, powielając zarówno recepty, jak i doniesienia autorów starożytnych. Przepis na „cudność lica” przewidywał użycie „obrasków abo wężownika białego (Aaron)”, sepii i bieli ołowiowej (blejwasu - hydroksowęglanu ołowiu $\mathrm{C}_{2} \mathrm{H}_{2} \mathrm{~Pb}_{3} \mathrm{O}_{8}$ ). Siennik napisał: „Też, kto chce mieć cudność lica nad przyrodzoną cudność, tak skóra była gładka, tak uczyń. Weź korzenia tego ziela, a uskub ie dobrze, weźmi też pół dragmy kości sepiyey (tak je zową w aptece), weźmi też ceruzy trochę mniej, a ono wszystko na proch bardzo miałki stłukłszy, zmieszaj $\mathrm{z}$ wodą różaną, a po tym, gdy się ustoi na dnie proch, tedy ono wodą umywszy z wierzchu lice, albo zmieszawszy, myj 


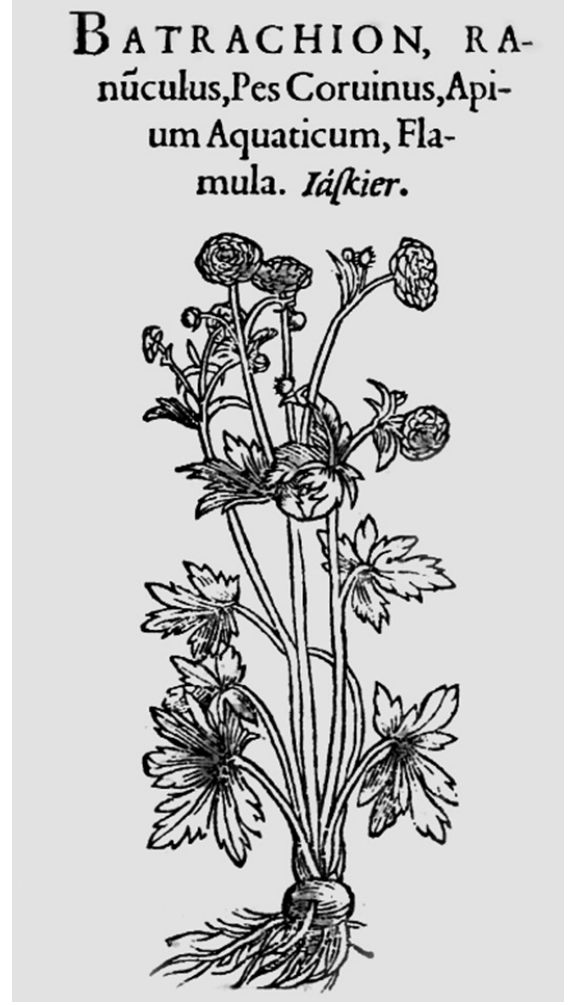

RYCINA 4. Jaskier. Fragment karty z „Herbarza...” Marcina z Urzędowa

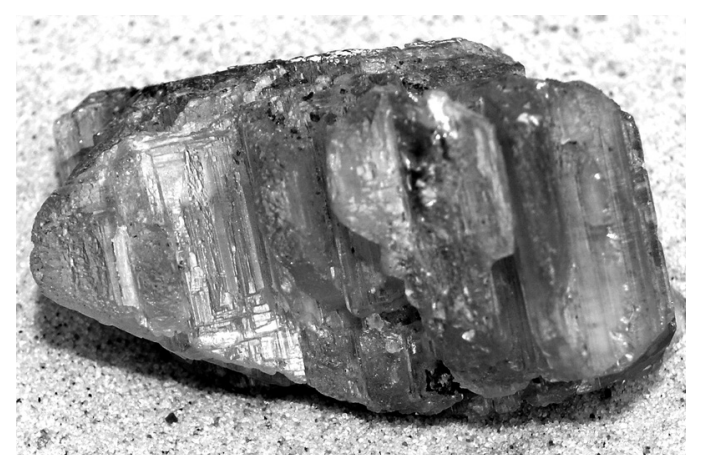

RYCINA 5. Cerusyt

twarz". Kość sepiya, szorstka os sepiae, wewnętrzny szkielet mątw zbudowany jest z węglanu wapnia, natomiast ceruzą nazywano cerusyt - węglan ołowiu $\mathrm{PbCO}_{3}$ (ryc. 5). Na piękną cerę rekomendował również nasiona melonów z dodatkiem krochmalu czy kwiaty grzybienia z blejwasem, jak również blejwas wymieszany z krochmalem: „Woda, w któreyby był rospuszczony blaywas z krochmalem, lice czyści paniam czyniąc ie lubieżne" [22].

W „Herbarzu...” Siennik podawał liczne przepisy na spędzanie piegów: „sok z tego ziela z trochu octu, gdy tym pomażesz, piegi znikną z lica" - pisał o babce, prawie dosłownie, jak wcześniej wspomniany Falimirz. Piegom miały również zaradzać „korzeń przestępowy stłuczony z Foenum Graecum”, czyli korzeń przestępu białego (Bryonia alba-Cucurbitaceae) zmieszany z kozieradką (Trigonella foenum-graecum - Fabaceae): „spędza piegi i insze nieczystości, blizny i też siność, która bywa pod oczyma". Siennik polecał sok z przestępu również jako środek depilacyjny - „spędza sierść s skóry”. Innym środkiem spędzającym „sierść” ze skóry był „złotołusk”, jak określał aurypigment, jednakże specyfik musiał mieć jeszcze silniejsze działanie niż te wspomniane przez Marcina z Urzędowa, bowiem dodawano do niego wapna: „Ma moc włosy z ciała wygrywać, a najwięcej z wapnem niegaszonym zmieszane, a na ciało skądkolwiek by chciał spędzić posypuj, albo zmieszawszy z sokiem romanowego ziela namazuj miejsce, gdzie włosy są" [22].

O lilii złotogłów (Lilium martagon - Liliaceae) pisał: „Korzeń złotogłowiu z bożym drzewkiem w ługu warzony, włosy rości i krosty spędza, a gdy korzenie uważym z otrębami pszenicznemi w wodzie, a tem lice będziesz mył, ogorzelinę i inne nieczystości z lica spędza”. „Listki konopne z bożym drzewkiem w ługu warzone, są pożyteczno, kto by się mył tym ługiem, tedy włosy długie czyni i głowę bardzo czyści”. Wśród mnogich recept na porost włosów wymieniał okrutny sposób pozyskiwania niektórych składników: „Popioł z żaby w garncu żywo palonej z miodem zmieszawszy, albo z mazią, na łysej głowie włosy rodzi”. Doradzał też użycie ekskrementów zwierząt „łayno mysie” miało zapobiegać parchom i wypadaniu włosów, „jaszczorce łayno, flaki żółte y piegi na twarzy spędza precz”. Natomiast krew jaszczurki „włosam pod pachą róść nieda” [22].

W rozdziale „O lekarstwach głowy” Siennik zamieścił sposoby barwienia włosów. Krucze jajo, bocianie „iaie”, krew z czarnego bydła, jajko jaskółki miały czernić włosy, natomiast „woda z kreta warzona, z czarnej sierści uczyni białą”. Rozjaśniać włosy miał wywar z kwiatu dziewanny lub z korzenia celidonii (glistnika jaskółczego ziela). Czerniły włosy pędy róży warzone w ługu czy sok z kwiatów bobu „w ołownym moździerzu na słońcu utłuczone". W rozdziale tym autor zamieścił również porady dotyczące wzrostu włosów na brwiach. Aby brwi urosły, należało się nachylać nad dymem z palonej sosny bądź też skorzystać z ususzonej śledziony osła, którą należało zmieszać z oliwą i sadłem niedźwiedzim. Włosy zbędne likwidować miały m.in. krew z zielonych żabek, z węża, z nietoperza, jak i „rdza żelazna szczynami rozpuszczona”. Radził również, jak wyrywać włosy z powiek - albo szczypczykami żelaznymi, albo smarując palce ży wicą. Rekomendował psią krew, „robaczki w nocy świecące”, pijawki z octem silnym, jak i robaki z nieświeżego mięsa zalane octem. Paleniu wódek poświęcił osobny rozdział. Powielał w nim wszystkie przepisy podawane przez Falimirza i Spiczyńskiego [22].

Znakomity botanik - Józef Rostafiński (1850-1928) jeszcze w XIX w. dokonał porównań tekstów Falimirza, Spiczyńskiego i Siennika, powołując się na wypowiedź Lelewela z 1823 r., który przypuszczał, „że zapewne wszystkie te zielniki są przedrukami pierwszego" [23]. Porównanie istotnie dowiodło, iż swoimi treściami niewiele odbiegały od siebie, ale różniły się ich układem [24]. Bardziej wnikliwe porównanie tych herbarzy zostało dokonane przez Jana Szostaka [11].

Marcin Siennik zapewne odczuwał niedosyt podawanych prze siebie receptur środków kosmetycznych, gdyż zdecydował się dodać do swojego „Herbarza...” jako suplement „Alexego Pedemontana Księgi ośmioro o tajimnych a skrytych Lekarstwiech”, gdzie w „Przedmowie do czytelnika” napisał, dlaczego księga została przetłumaczona. Podawał, iż lekarz cieszył się 
wielką sławą w wielu państwach, ze względu na podawane recepty leków, zwłaszcza tych na morowe powietrze. „Nad to pisał ten zacny mąż, niepospolite sprawy ku ochędożeniu Ludzkich ciał y ku zgładzeniu rozmaitych niedostatków płci" [22].

Już zawartość pierwszych rozdziałów księgi I wskazuje, iż kwestie morowego powietrza zostały zepchnięte na drugi plan przez „niepospolite sprawy ku ochędożeniu”. Rozdział pierwszy otwiera recepta „0 bieleniu włosów na głowie bez słońca”, następne dotyczą włosów kędzierzawienia, kolejne „Włosów żółcenie iako złoto rozmaitym obyczaiem”, dalej „Na toż oleyek pewny, który i twarz łśni”, dalsze strony zajmowały przepisy dotyczące farbowania włosów na kolor blond. Farbowanie włosów na czarno i rudo zajmowało znacznie mniej miejsca [25]. Rozdział drugi „0 mnożeniu włosów, bądź na głowie albo indzie, zwłaszcza tam, gdzie obłażą i iako im lezienia bronić i odzieżane mocnić” omawiał wzmacnianie włosów i ich depilację. Zawierał przepisy w rodzaju: „Weźmi mózgu nietoperzego a zetrzyj z mlekiem niewieścim. Weźmiesz też bluszczowy klej a rozetrzyj go z bykową żółcią i tem pomazuj” czy „Młodych Jaskółcząt uwiercić z Bobrowym stroiem, octem mocnym rostworzywszy, wley to w Alembig, a upal wodkę, te włosy zgubisz". Kolejny rozdział dotyczył parchów na głowie, gnid i wszy (aby włosów nie szpeciły). Rozdział 7 „O nozdrzy gniciu i ust śmierdzeniu”, rozdział 8 - „0 zganianiu zmaz licnych...”, rozdział 9 - „Na gładzenie lica gdy go kto malować nie chce”, rozdział 10 - „O rumienieniu lica y iako zbytnią abo y szkodliwą czerwoność spędzać”. Rozdział 10 umieszczono 2-krotnie, gdyż kolejny zajmuje się odmłodzeniem twarzy i rozpędzeniem zmarszczek. Aleksy z Piemontu powtórnie powraca do tematu zmaz, piegów, brodawek, by księgę I zakończyć bieleniem zębów. Recepty, np. na gładzenie lica, można uznać za mocno skomplikowane. „Weźmij miałko tartego szkła 4 uncye, czerwonego koralu też miałkiego 3 uncye, białego cukru 4 uncje, hałunu 1 uncya. W ty wszystkie prochy włóż rtęci półtorej uncje, coby ślinami była wzmorzona, wbijże świeżych jajek 12, wespół z skorupami stłukłszy, terpentyny dziewięćkroć płukanej 4 uncye, ślimaki morskie białe, co je kadzielnicy we Włoszech sprzedają - 2 uncye, ślimaki ziemne 50, To wszystko stłuc i wespół zmieszać. Włóż naprzód część tego do bańki szklaney, potym część wprzód mielonych prochów, potym część terpentyny, potym część jednych ślimaków na część drugich. Rzas także ostatek wkładaj warstwami. $\mathrm{Na}$ ostatek przylej wina białego quartę, palże to ogniem lekkim, a onę wodkę w bance szklanej choway". Na rumianość lica zalecał wysoce złożone preparaty, np. z wódki wypalonej z mięsa specjalnie karmionych gołębi, listków złota i srebra, ałunu cukrowego, szpiku wołowego [25].

Do tematu kosmetyków powrócono w księdze VI. Znalazły się w niej m.in. przepisy „O wonnych wodach tak zdrowiu iako y lubościam służących”, „O gałkach albo pacierzach wonnych ku noszeniu przy sobie dla woniey”, „0 tłustościach wonnych ku mazaniu rękawic dla woniey przyjemney”, „0 przyprawianiu mydła wonnego". Następnie Pedemontano zajął się szatami, olejkami do szat i ciała, a nawet pachnidłami stosowanymi do pościeli, by zakończyć księgę gubieniem pcheł [25].
Bela szczegółowo opracował zawartość pracy Aleksego z Piemontu w swoich publikacjach $[5,6,7,8,10]$, zwracając uwagę na miejsce tzw. sekretów w ówczesnej Europie.

Kolejnym i największym z zielników renesansowych, nie tylko w Polsce, ale i w Europie, było dzieło Szymona Syreniusza (1540-1611), które ukazało się już po śmierci autora, w XVII w. [26]. Przytaczał w nim wcześniej już opisane informacje „kosmetyczne” o roślinach, wymieniając ich kilkadziesiąt, jednakże nie zostaną tutaj wymienione ze względu na zakreślone ramy chronologiczne, tym bardziej, że sprawą kosmetyków, w przeciwieństwie do swoich poprzedników, zajmował się niejako na uboczu, jednakże wypada zauważyć, że jedynie Marcin z Urzędowa i Szymon Syreński stworzyli zielniki nieopierające się tylko na tłumaczeniach łacińskich tekstów, lecz również na własnych obserwacjach i poszukiwaniach. Po powrocie z zagranicznych wojaży do Włoch, Szwajcarii, Niemiec i Węgier Syreniusz poświęcił swój czas poznawaniu roślin krajowych, udając się na południe Polski. Często sięgał po informacje uzyskane od innych badaczy, np. lekarza Jerzego Grembsa o ziołach rosnących na Litwie [27].

Omawiając polskie „ogrody zdrowia”, zwane mniej czy bardziej słusznie „zielnikami”, wypada się zastanowić, do jakich adresatów były one kierowane. Na pewno do tych, których było na księgi stać - cena była niemała, jednakże konkretnie Syreniusz w długim tytule „Zielnika...” wymienia potencjalnych czytelników: „Księga lekarzom, aptekarzom, cyrulikom, barbirzom, roztrucharzom, końskim lekarzom, mastalerzom, ogrodnikom, kuchmistrzom, kucharzom, synkarzom, gospodarzom, mamkom, paniom, pannom y tym wszystkim którzy się kochają y obieyrzą w lekarstwach" [26]. Jak z tego wynika, sztuka czytania albo słuchania czytanych tekstów była bardziej rozpowszechniona niż się obecnie przypuszcza. Można domniemywać, że zapewne jego poprzednicy również mieli na uwadze te same grupy potencjalnych użytkowników herbarzy.

Proponowane w zielnikach środki kosmetyczne można podzielić na 4 kategorie dotyczące skóry, włosów i paznokci, zębów i jamy ustnej oraz zapachów.

\section{SKÓRA}

\section{Pięknidta dla polepszenia kondycji i pielęgnacji skóry}

Do tej grupy wchodzą różnego rodzaju maseczki (np. z przeżutego bobu, cynamonu), toniki, alkohole do oczyszczania skóry, tłuszcze pochodzące od ptaków (kurze, kacze, gęsie i łabędzie) do pielęgnacji warg, skóry twarzy, maści, roślinne środki wygładzające skórę i zmarszczki i likwidujące worki pod oczyma. Powszechnie rekomendowana była krew zajęcza. Stosowano dermabrazję (peeling), do czego najczęściej służyła sproszkowana sepia i skóra z rozparzonych, szorstkich nóg kurzych.

\section{Lekarstwa likwidujące patologiczne zmiany skórne}

Środki do likwidowania zmian skórnych, takich jak: krosty, parchy, świerzb, liszaje, zaskórniaki i trądy, przy czym trudno powiedzieć, co kryło się pod tym określeniem - być może różnego typu owrzodzenia lub zmiany spowodowane przez syfilis, 
to kolejna grupa specyfików. O obecności trądu wśród tych schorzeń i jego zanikaniu świadczy jedyna recepta na „gnijące nozdrza” (Aleksy z Piemontu). Wśród proponowanych lekarstw nie ma za wiele preparatów z rtęci (jak się wydaje dopiero Aleksy z Piemontu więcej o niej pisze), natomiast stosuje się różnego typu alkohole.

\section{Usuwanie blizn}

Problem usuwania blizn szerzej pojawił się dopiero w pracy Marcina z Urzędowa. Jego poprzednicy nie zwracali na to zagadnienie uwagi. Nie interesowano się powodami ich powstawania ani tuszowaniem zmian skórnych.

\section{Piększydta do likwidowania przebarwień i dla nadania cerze białości}

Ogorzelina, czyli opalenizna, zwłaszcza u eleganckich kobiet w ówczesnej Europie była niemile widziana, świadczyła bowiem o wykonywaniu pracy na świeżym powietrzu i plebejskości. Zwalczano ją np. za pomocą boraksu, kamfory, ałunu, saletry, rtęci, deszczówką zmieszaną z winem, serwatką. Duża liczba środków do likwidacji piegów zdaje się świadczyć o tym, że był to mocno niepożądany element urody. Oprócz serwatki, krochmalu, rozlicznych roślin, którym przypisywano wybielające właściwości, stosowano wysokotoksyczne - hydroksowęglan ołowiu (biel ołowiową, blejwas) $\mathrm{C}_{2} \mathrm{H}_{2} \mathrm{~Pb}_{3} \mathrm{O}_{8}$ i węglan ołowiu $\mathrm{PbCO}_{3}$ (cerusa), którymi pudrowano twarz i dekolt. Były to powszechnie używane w ówczesnej Europie remedia.

\section{Piększydła służące do rumienienia policzków}

„Rumienność lica” powodowała np. wódka anyżowa, inne wódki, lecz również korzystano z soku czerwonych owoców czy warzyw. Przepisy na „niepospolite barwiczki” podawał dopiero Aleksy z Piemontu.

\section{WŁOSY I PAZNOKCIE}

\section{Środki na porost i wzmocnienie włosów}

Służyły do tego celu bardzo liczne środki - najróżniejsze wódki (np. wódka rozmarynowa czy pędzona z wierzbówki), jaja ptaków, wywary i napary z ziół.

\section{Zwalczanie tupieżu}

Falimirz podawał recepturę jednego lekarstwa do zwalczania łupieżu, natomiast w innych zielnikach, jak się wydaje, nie zwracano na ten problem uwagi.

\section{Środki depilacyjne}

Niektóre podawane środki depilacyjne można zaliczyć do mitycznych, np. krew z zielonych żabek czy krew z węża lub nietoperza miały nie dopuszczać, by wyrastały włosy na brwiach, co było pozostałością jeszcze średniowiecznej mody. Jednak już w herbarzu Marcina z Urzędowa znalazły się informacje, jak należy pielęgnować brwi. Pisał o nich również Marcin Siennik. Zarówno Falimirz, Spiczyński, Siennik, jak i Marcin z Urzędowa jako bardzo skuteczny środek depilacyjny polecali aurypigment - rzadko występujący trisiarczek diarsenu $\left(\mathrm{As}_{2} \mathrm{~S}_{3}\right)$ wprowadzony przez alchemików arabskich. Marcin z Urzędowa nazywał aurypigment arseniconem i opisywał jego ogryzającą moc. Na wzór arabski niekiedy mieszano aurypigment z wapnem, co czyniło go jeszcze bardziej skutecznym. Aurypigment, nazywany czasem złotołuskiem, od średniowiecza służył także do wykonywania złoceń na pergaminach.

\section{Farby do włosów}

Bardzo dużą wagę przykładano do barwienia włosów, o czym świadczy mnogość przepisów u wszystkich autorów. Preferowano włosy jasne bądź czarne. Uznaniem nie cieszył się rudy i niewiele można było znaleźć informacji o barwieniu włosów na ten kolor, niemniej Marcin z Urzędowa podawał, że skuteczny jest kamień winny (wodorowinian potasu $\mathrm{KC}_{4} \mathrm{H}_{5} \mathrm{O}_{6}$ ). Korzystanie z jaj ptaków nie farbowało na ogół włosów, niemniej po nie sięgano. Rośliny, których użycie zalecano, stosowane są najczęściej nadal (np. kozieradkę współcześnie używają zarówno mieszkańcy Afryki Północnej, jak i Hindusi). Odkryty przez Alberta Wielkiego azotan srebra $\left(\mathrm{AgNO}_{3}\right)$, nazywany w przeszłości lapis infernalis, czyli piekielnym kamieniem, pozostawiał po sobie trudno zmywalne czarne plamy i często był stosowany jako dodatek do czarnych farb.

\section{Pielęgnacja paznokci}

Najszerzej pielęgnację paznokci opisał Marcin z Urzędowa. O stosowaniu na płytkę paznokcia wysoce toksycznego soku z różnych gatunków jaskrów pisał Dioskurides. Powoływano się na jego recepty w całej średniowiecznej i renesansowej Europie [28]. Ze środków chemicznych stosowano ałun - uwodniony siarczan potasowo-glinowy $\left(\mathrm{KAl}\left(\mathrm{SO}_{4}\right)_{2} \cdot 12 \mathrm{H}_{2} \mathrm{O}\right.$ - oraz siarkę.

\section{ZĘBY I JAMA USTNA}

\section{Tuszowanie przykrego zapachu z ust}

W XVI w. nieprzyjemny zapach z ust pochodził nie tylko z powodu próchnicy zębów, lecz powodowany był również przez szkorbut pojawiający się najczęściej zimą i na przednówku. Chociaż szkorbut, zwany inaczej gnilcem, był chorobą opisywaną już przez Hipokratesa, dopiero węgierski biochemik, laureat Nagrody Nobla - Albert Szent-Györgyi w 1932 r. stwierdził, że kwas heksuronowy skutecznie go leczy. Jednocześnie dokonano odkrycia kwasu askorbinowego [29]. W 1933 r. Szent-Györgyi wyizolował witaminę C. Wcześniej w nauce nie wiązano błędów dietetycznych ze szkorbutem.

Tuszowanie przykrego zapachu z ust z powodu chorób lub spożywania czosnku i cebuli stanowiło w przeszłości ważki problem. Głównie używano do tego celu wódki, np. miętową bądź różaną, ale rekomendowano także żucie owsa, piołunu lub zamorskie rośliny, wśród nich citrowe jabłko. Cytryny zaczęto uprawiać w ciepłych rejonach Europy w czasach krucjat.

\section{Utwierdzanie chwiejących się zębów}

Chwianie się zębów stanowiło w dobie Odrodzenia nie tylko skutek nierozpoznawanej wówczas paradontozy, lecz również 
szkorbutu. Usiłowano schorzenie leczyć, ale wódki nie stanowiły skutecznego remedium, podobnie jak proponowane napary i wywary z ziół.

\section{Bielenie zębów}

Pod nazwą bielenie kryło się czyszczenie uzębienia. Renesansowi mieszkańcy Europy nie dysponowali jeszcze szczoteczką wynalezioną w Europie w końcu XVIII w. Środków na bielenie zębów nie było podanych zbyt wiele - Falimirz zamieścił jeden przepis, inny autor - dwa. Można zakładać, że środki należały do mało skutecznych. Prawdopodobnie chłopski zwyczaj z XIX w. - czyszczenie zębów za pomocą skórki od chleba lub zwęglonej skórki od chleba [30] - mógł być w użyciu już w renesansowych czasach. Liczne przepisy zawierała praca Aleksego z Piemontu [25].

\section{ZAPACHY}

\section{Likwidowanie zapachu potu}

Jako skuteczne środki polecano niektóre wódki, np. ałunową, którą aplikowano na stopy, w okolicach genitalii, jak również pod pachami.

\section{Pachnidła}

Renesansowa woda stosowana po goleniu pachniała kamforą, lecz dziś zapewne nie cieszyłaby się uznaniem. Ceniono i polecano wódkę różaną, lecz także inne rodzaje wódek - np. konwaliową (lanczaną), werbenową (koszyczkową). Wytwarzano również pachnące olejki, jak i mieszaniny przypraw z winem. Smarowano pachnidłami nie tylko skórę, lecz również odzież. Jeszcze w średniowieczu rycerze wracający z wypraw krzyżowych rozpowszechnili pachnące różami lub jaśminem saraceńskie rękawiczki. Wkrótce stały się one modne w całej Europie. Do kufrów z ubraniami wkładano zioła, by ich zapach odstraszał mole, jednak te najbardziej skuteczne (np. bagno Ledum palustre) nie cieszyły się uznaniem z powodu ostrej woni. Różnego rodzaju zioła wkładano do pościeli, np. piołun, rumianek. Miały one nie tylko nadawać pościeli ładny zapach, ale przede wszystkim chronić przed inwazją pasożytów. W przeciwieństwie do Pedemontana, polscy autorzy zielników podawali dość proste sposoby wytwarzania pachnideł. Ciężkie zapachy gwarantował strój bobrowy (kastoreum), lecz sprowadzano do aptek także piżmo. Jak można mniemać, niektóre zagraniczne pachnidła, sporządzone np. z goździków lub cynamonu, musiały bardzo drogo kosztować. Dla wielu mężczyzn ich stosowanie świadczyło o zniewieścieniu.

\section{WNIOSKI}

Abstrahując od skuteczności proponowanych w zielnikach środków czy ich w dużej mierze magicznej proweniencji, mnogość informacji o charakterze kosmetycznym, jak również tłumaczenie pracy Aleksego z Piemontu niezbicie świadczą o tym, iż potrzeby estetyczne względem własnego ciała nie różniły mieszkańców Polski od obywateli innych krajów europejskich. Również wznawianie zielnika Falimirza, naśladowcze działania Spiczyńskiego i Siennika mogą wskazywać, że nie tylko oczekiwano wiedzy o leczeniu, ale również o chędożeniu. Dodanie „Sekretów” Aleksego z Piemontu do herbarza opracowanego przez Siennika stanowiło odpowiedź na społeczne zapotrzebowanie. „Segreti del reverendo donno Alessio Piemontese" wznawiano w Europie jeszcze w końcu XVIII w. - i jak twierdził Zbigniew Bela - czyniono tak ok. 170 razy [31].

\section{PIŚMIENNICTWO}

1. Wdowiak L. Kosmetyki w średniowiecznej Europie. In: Korpalska W, Ślusarczyk W, editors. Czystość i brud. Higiena w średniowieczu Bydgoszcz: Wydaw. Naukowe Uniwersytetu Mikołaja Kopernika; 2014. p.111-24.

2. Jankowiak W. Kosmetyki w praktyce aptecznej i przemysłowej na ziemiach polskich do roku 1939 [dissertation]. Poznań: Uniwersytet Medyczny im. K. Marcinkowskiego w Poznaniu; 2015. www.wbc.poznan.pl/Content/356517/index.pdf (5.09. 2016).

3. Brückner A. Słownik etymologiczny języka polskiego. Warszawa: Wiedza Powszechna; 1970. p. 412.

4. Zemanek A. Botanika Renesansu w świetle współczesnej nauki. Wiad Botan 1997;41(1):7-19.

5. Bela Z. Sposoby preparowania tzw. wódek w Herbarzu Polskim Marcina Siennika (Kraków, 1568). Farm Pol 2010;66(12):851-8.

6. Bela Z. Przepisy na leki i kosmetyki w Sekretach Aleksego z Piemontu (XVI wiek), In: Marona H, editor. Medyczne aspekty kosmetologii. Kraków: Wydawnictwo Abaton; 2010. p. 7-13.

7. Bela Z. Alexego Pedemontaná táiemnice. Kraków: Medycyna Praktyczna; 1999.

8. Bela Z. Eksperymenty i sekrety. Farm Pol 2001;57(1):47-52.

9. Kuchowicz Z. Uwagi o konsumpcji produktów destylacji alkoholowej w Polsce w XVI w. Kwart Hist Kult Mater 1971;19(4):667-8.

10. Bela Z. Wódki w Herbarzu Marcina Siennika. Panacea 2010;4:32-4.

11. Szostak J. Farmakognozja, farmacja galenowa i aptekarstwo w renesansowych zielnikach. Warszawa: Wydawnict wo Lekarskie PZWL; 2006.

12. Siennik M. Lekarstwa doświadczone, które zebrał uczony lekarz pana Jana Pileckiego, któremu są przydane lekarstwa końskie z cwiczeniem tego lekarza: Przydaliśmy y figury zioł rozmaitych ku lekarstwu z ziołkami dostatecznemi sprawione, teraz znowu na światło wydane. Kraków: Łazarz Andrysowic; 1563.

13. Szostak J. Vademecum lecznictwa domowego z roku 1563. Warszawa: Poligraf; 2016.

14. Drobnik J. Zielnik i jego znaczenie dla poznania leku roślinnego. Panacea 2009;2:24-5.

15. Macer A. De Herbarum virtutibus cum veris figuris herbarium. Graduationes simplitium cum Nomenclatura \& interpretatióe Polonica herbarum \& morburŭ secundum seriem Alphabeti. In calce huius operis, addida est expositio terminorum obscurorŭ cótentorum in hoc opere. Per Simonem de Louicz artrum \& medicinae doctorem. Kraków: Officina Ungleriana; 1537.

16. Ziembicki W. Szymona z Łowicza „Aemilius Macer de Herbarum Virtutibus”. Egz. wyd. z r. 1532. Arch Hist Filoz Med Hist Nauk Przyrod 1929;9(1):23-9.

17. Falimirz S. O ziołach i mocy ich. Kraków: Florian Ungler; 1534.

18. Frankowska M. Nazwy roślin i ich źródła w Słowniku języka polskiego Samuela Bogumiła Lindego. Folia Toruniensia 2008;8:27-56.

19. Spiczyński H. O Ziolach tutecznych y zamorskich y o mocy ich, a kthemu kxięgi lekarskie wedle regestru niżey nowo wypisanego wssem wielmi użyteczne. Kraków: Helena Unglerowa; 1542.

20. Marcin z Urzędowa. Herbarz Polski, To iest o Przyrodzeniu Zioł Y Drzew Rozmaitych, Y Inszych Rzeczy do Lekarztw Należących, Księgi Dwoje, Doctora Marcina Urzędowa, Kanonika niekiedy Sędomierskiego: y Iaśnie oświeconego Hrabie Pana, Pana Iana z Tarnowa, Kasztellana Krakowskiego, y Hetmana Wielkiego Koronnego, etc. Medyka. Kraków: Drukarnia Lazarzowa; 1595, p. 46-474.

21. Dłużewski S. Dzieło Marcina z Urzędowa. Panacea 2004;1:31-2. 
22. Siennik M. Herbarz to jest ziół tutecznych, postronnych i zamorskich opisanie, a iaką moc maią i iako ich używać ku przestrzeżeniu zdrowia ludzkiego, iako ku uzdrowienia rozmaitych chorob: Teraz nowo wedle herbarzow dzisieyszego wieku y inych zacnych medyków poprawiony. Przydano Alexego Pedemontana Księgi Ośmiory, o taiemnych a skrytych Lekrstwiech: przy czym dosyć misternych a trafnych rzeczy y doświadczonych mieć będziesz. Kraków: Drukarnia M. Szarffenberger; 1568.

23. Rostafiński J. Nasza literatura botaniczna XVI w. oraz jej autorowie lub tłumacze. Studyjum krytyczne. Kraków: Druk. Uniwersytetu Jagiellońskiego; 1888.

24. Rostafiński J. Porównanie tak zwanych zielników Falimirza, Spiczyńskiego i Siennika. Kraków: Druk. Uniwersytetu Jagiellońskiego; 1888.

25. Alexego Piedemnontana Księgi Ośmiory, o taiemnych a skrytych Lekrstwiech: przy czym dosyć misternych a trafnych rzeczy y doświadczonych mieć będziesz. In: Siennik M. Herbarz to jest ziół tutecznych, postronnych i zamorskich opisanie, a iaką moc maią i iako ich używać ku przestrze żeniu zdrowia ludzkiego, iako ku uzdrowienia rozmaitych chorob: Teraz nowo wedle herbarzow dzisieyszego wieku y inych zacnych medyków poprawiony. Kraków: Drukarnia M. Szarfenberger; 1568

26. Syreniusz S. Zielnik, herbarzem z ięzyka łacińskiego zowią, to iest opisanie własne imion, kształtu, przyrodzenia, skutków y mocy zioł wszelakich drzew, krzewin y korzenia ich, kwiatu, owoców, soków, miazg y żywic y korzenia do potraw zaprawowania; także trunków, syropów, wódek, lekiwarzów, konfektów, win rozmaitych, prochów, soli z zioł czynioney; maści, plastrów; przytym o ziemiach y glinkach różnych, o kruscach, perłach y drogich kamieniach. Też o zwierzętach czworonogich, czołgaiących, ptastwie, rybach, y tych wszystkich rzeczach, które od nich pochodzą: od Dioskorida z przydaniem y dostatecznym dokładem z wielu innych o tey materiey piszących, z położeniem własnych figur dla snadnieyszego ich poznania y używania ku zachowaniu zdrowia tak ludzkiego iako y bydlęcego, y chorób przypadłych odpędzenia, z wielkim uważeniem y z rozsądkiem. Polskim ięzykiem zebrany y na ośmioro ksiąg rozłożony. Księga lekarzom, aptekarzom, cyrulikom, barbirzom, roztrucharzom, końskim lekarzom, mastalerzom, ogrodnikom, kuchmistrzom, kucharzom, synkarzom, gospodarzom, mamkom, paniom, pannom y tym wszystkim którzy się kochają y obieyrzą w lekarstwach. Pilnie zebrane a porządnie spisane przez D. Simona Syreniusza. Kraków: Drukarnia Bazylego Skalskiego; 1613.

27. Kosmiński J. Słownik lekarzów polskich obejmujący oprócz krótkich życiorysów lekarzy Polaków oraz - cudzoziemców w Polsce osiadłych, dokładną bibliografią lekarską polską od czasów najdawniejszych aż do chwili obecnej. Warszawa: nakł. aut.; 1883. p. 151.

28. MacVaugh MR, Sinclair Ogden M. Guigonis de Caulhiaco (Guy de Chauliac) Inventarium sive Chirurgia Magna. T. 2. New York, Köln, Leiden: Brill; 1997.

29. Dzierżanowski R. Słownik chronologiczny dziejów medycyny i farmacji. Warszawa: PZWL; 1973. p. 330.

30. Ziemba JS. Przyczynek do lecznictwa ludowego. Wisła 1890; 4(2):439.

31. Bela Z. Olejku dziurawcowego przyprawianie, który w Wenecyjej czerwonym zową. Panacea 2005;4:32-4. 